\title{
Proposing a Theoretical Framework to Investigate the Relationships between an Organization and its Environment
}

\author{
Ricardo Corrêa Gomes \\ Luciana de Oliveira Miranda Gomes
}

\section{RESUMO}

Este trabalho propõe um modelo teórico de investigação da teoria dos stakeholder nas organizações. A teoria das organizações é modernamente dividida em modelos racionais, naturais e de sistema aberto. Neste artigo é apresentada uma classificação, que combina os três modelos citados justificando que, dadas as especificidades das organizações como sistema social, para se analisar o comportamento de uma organização é necessário que ela seja entendida nos aspectos natural e de sistema aberto. As aplicações deste artigo residem na utilização de um referencial teórico que é baseado em uma extensa revisão de literatura focada em teorias que buscam explicar o relacionamento organizações-ambiente. Desta forma, o artigo poderia ajudar os pesquisadores que estão envolvidos em desenvolver teorias que tenham como objetivo entender o comportamento das organizações ao serem influenciadas por seus ambientes e, também, explicar o relacionamento destas com agentes externos. As teorias de dependência de recursos e institucional são utilizadas para proporcionar maior suporte teórico à teoria dos stakeholder. No final do trabalho será apresentado um diagrama representando o modelo teórico que possibilita a investigação cientifica do comportamento das organizações frente a influências do meio em que vive.

Palavras-chave: teoria das organizações; revisão de literatura; teoria dos stakeholder; teoria da dependência de recursos; teoria institucional

\begin{abstract}
This paper proposes a theoretical framework for investigating stakeholder theory in organizations. The organizations theory can be understood in three theoretical models: rationalist, natural and open systems. These models are presented to justify that organizations should be analyzed taking into account that social system aspects and the natural and open system models are employed. The applications of this paper rely upon the theoretical framework which is based on an extensive literature review comprising environment based theories. This paper would be of help to researchers examining the whole set of the relationship of organizations with their environment instead of only the relationships with external agents. Employing the theoretical basis presented in this analysis, the researcher will be able to identify both feasible theoretical sources for his/her studies and useful approaches for carrying on his/her investigations. The paper presents theories for explaining the organization's behavior and performance as being influenced by stakeholders who inhabit its environment. Resource dependence and institutional theory are employed to give theoretical support to the stakeholder. At the end of the paper, a diagram representing the theoretical framework is presented.
\end{abstract}

Key words: organizations theory; literature review; stakeholder theory; resource dependence theory; institutional theory. 


\section{INTRODUCTION}

This paper proposes a theoretical alternative for investigating the relationships between public organizations and their environment. The framework proposed here does not pretend to be normative on proposing the best way, because there are other good theoretical alternatives for explaining this type of social phenomenon.

The stakeholder theory has been employed as a theoretical background for investigating the relationships between a given organization (public and private types) and its environment. The justification for this approach relies upon the fact that this theory is flexible enough to cover technical and institutional aspects of the phenomenon. Thus, stakeholder theory helps to explain how an organization gets involved with people, groups and other organizations from its environment due to resource needs and due to the necessity for acceptance and legitimacy.

The paper starts by outlining organizations theory in order to understand the utility of environment-based theories for explaining an organization's behavior and performance. For this reason, it starts discussing the various concepts of organizations as well as the different levels by which the organizations' structure, behavior and performance are likely to be analyzed.

After focusing the level of analysis within organizations theory, the analysis indicates resource dependence and institutional theories as feasible approaches for understanding the relationships between organizations and environmental influences. Finally, the results of the literature review are merged into a theoretical framework, which identifies an alternative approach to investigate the phenomenon in all types of organization.

\section{Preliminary Insights in the Organizations Theory}

\section{Understanding the Dimensions of the Organization's Concept}

Scott (1998, p. 23-25) argued that organizations are system with rational, natural and open characteristics. As rational systems, organizations are formalized structures seeking to achieve goals. As natural systems, organizations are seen as entities struggling for survival within their environment. Finally, as open systems, organizations are entities that exist in that they can establish relationships with 
their environment. He observed that organizations theory evolved from the combination of these three approaches in the development of 'new' theories and an understanding the organization's behavior and performance has resulted. These new theories are:

. Open and Rational Models that resulted from the combination of open systems with rationalistic approaches. In these theories, academics are concerned with how an organization transforms its structure and behavior in order to be able to face new realities and demands. The main models in this category are the Contingency Theory (Lawrence \& Lorsch, 1967), Comparative Structure (Woodward, 1965), and Transaction Cost Analysis (Williamson, 1975);

. Open and Natural Models that resulted from the combination of open systems with naturalistic approaches. These models seek to understand how an organization's behavior can be seen as a result of environmental forces. In this vein, an organization's structure and action is likely to be guided by externally created rules and patterns of behavior. The main models in this category are: Strategic Contingencies (Child, 1973), Population Ecology (Hannan \& Freeman, 1977), Resource Dependence (Pfeffer \& Salancik, 1978), and Institutional Theory (Selznick, 1966).

Analyzing Scott's typologies for the organization concept, one might conclude that there is no point in studying an organization as being detached from its environment. Indeed, an organization constantly exchanges influences with its environment, and this fact is likely to explain its behavior and performance. In this vein, Child (1976, p. 2) argued that: "No organization operates in a vacuum". In accordance with Child's argument, there is Lawrence \& Lorsch's Contingency Theory (1967, p. 157), which was proposed to explain environmental influences on organizations, in which the basic assumption was: "organizational variables are in complex interrelationship with one another and with conditions in the environment". Another perspective in this vein is the Darwinian perspective (Hannan \& Freeman, 1977) in which organizations keep moving forward looking for adaptation, fitting and, therefore, survival.

Based on the arguments above, it is reasonable to assume that an organization's behavior and performance can be explained by open and natural concepts of organization because it is the way in which the relationships between organizations and their environments can be understood.

\section{Understanding the Meaning of an Organization's Analysis}

Scott (1998, p. 15) argued that an organization can be analyzed at three levels: the social psychological, the structural and the ecological. They are detailed as follows: 
. The social psychological level deals with the individual behavior of people within the organization. It is concerned with "the interpersonal relations involving individuals participating within an organization".

. The structural level deals with the analysis of the formal organization, i. e., it takes into account the structural design as well as the role of each unit related to the whole organization.

. The ecological level deals with the analysis of the environment within which the organization is inserted. At this level, the analysis can be focused either on the relationship between a specific type of organization and its environment, or on a specific class of organization in relation to its environment.

\section{Understanding the Organization's Environment}

Pfeffer and Salancik (1978, p. 12) suggested that the organization's environment can be defined as a set of external "events in the world which has any effect on the activities or outcomes of the organization". As a contribution towards understanding the organization's environment, Scott (1998) argued that the environment can be classified either by the levels at which it is composed or by the nature of the relationships linking the organization with its environment. The levels of analysis are: organization sets, organization populations, organization communities and organization fields (Scott, 1998; Scott \& Meyer, 1991). With regard to the nature of the relationships the emphasis is placed on the relationship between the organization and its environment and this relationship can be explained by technical or institutional issues (Scott, 1998). These situations are explained below.

The level of analysis of organization sets considers an organization in its unique form. A particular organization is analyzed in order to explain its relationships with other organizations and partners. The focus is placed on how these relations come about and how the organization deals with them in order to accomplish its goals.

At the organizational population level, the organization is analyzed as a specimen of a class (Scott \& Meyer, 1991). It seeks to explain the organization's behavior as the result of some patterned characteristics. Being able to explain the behavior of a single element of the class, the analyst is allowed to generalize this behavior to other elements from the same class. Hannan and Freeman (1977) applied this analogy to explain environmental influences as determinants of the organization's survival.

The organization community's level of analysis situates the organization as part of a geographical area. By applying this sort of analysis, the analyst is interested in understanding the network of relationships between a focal organization and 
others (similar or otherwise) that act in a specific geographical area. Scott (1998, p. 128-29) argues that in trying to explain an organization's behavior from this perspective, the theorist may be biased because in modern society "geographical boundaries are, for many purposes, meaningless".

Scott (1998) suggested that the organization's environment can be defined as technical or institutional, which are dealt with as follows.

The technical environment (also called the task environment) consists of technical activities related to "production and control technologies, patterns of interorganizational exchange, regulatory processes, and other factors that lead to relatively more or less efficient or effective forms of organization" (Orrù, Biggart, $\&$ Hamilton, 1991, p. 361). The task environment comprises the sources of inputs as well as the destinations for an organization's outputs (Scott, 1998). In other words, the technical environment is the arena in which organizations duel with people, groups or other organizations fighting for resources.

The institutional environment is "the socially constructed normative worlds in which organizations exist" (Orrù et al., 1991, p. 361). It consists of "the elaboration of rules and requirements to which individual organization must conform if they are to receive support and legitimacy" (Scott \& Meyer, 1991, p. 123). While the technical environment is a set of requirements under which the organization's productive process should be guided, the institutional environment creates a set of norms, beliefs and values by which the organization's behavior should be guided in order to achieve legitimacy (Greenwood \& Hinings, 1996).

\section{Understanding Environmental Influences}

Because organizations are social systems (Boulding, 1956), they exchange resources with their environment in order to achieve legitimacy. This is a precondition of the system within which they survive (Pfeffer \& Salancik, 1978). In these circumstances, an organization seeks links with others, looking for channels through which the required resources can be exchanged (Oliver, 1990). On the other hand, organizations also live in institutionalized worlds in which taken-for-granted practices are copied and transferred to the organizational fields (Oliver, 1997).

Institutional and Resource Dependence theories assume that an organization's behavior is significantly influenced by external pressures (Greening \& Gray, 1994; Oliver, 1991). These pressures come about in the form of resource exchange and isomorphism. Moreover, an organization is likely to survive to the extent that it can cope with external demands and expectations (Mwankwo \& Richardson, 1996; Oliver, 1991). 
Acknowledging these arguments, some authors argue that the process of depicting environmental influences on an organization starts with the identification of the external potential agents most likely to influence the organization (Ansof, 1988; Bryson, 1995; David, 1995; Freeman, 1984; Frooman, 1999; Greenley \& Foxall, 1997; Pfeffer \& Salancik, 1978; Roy \& Séguin, 2000). In this sense, the relationships between an organization and its main influential stakeholders might appear either in the form of interest in the organization's goals and performance or as a result of those stakeholders' power to influence the organization.

\section{Resource Dependence Theory as a Model for Understanding Environmental Influences}

In broad terms, this theory is based upon a set of relationships formed between an organization and its technical environment (Orrù et al., 1991). These relationships are normally based on the process of exchanging resources.

Pfeffer and Salancik (1978) suggested that the main tenets of this theory are:

- An organization behaves like its environment. In order to understand an organization's behavior, it is necessary to understand the environment in which the organization is inserted;

. An organization's survival is related to resource gains and preservation;

- An organization is said to be effective to the extent that it "is meeting the demands of the various groups and organizations that are concerned with its activities" (Pfeffer \& Salancik, 1978, p. 11);

- An organization depends on its environment, because its required resources are owned by agents who belong to that environment;

- "Managers and other stakeholders can, to a degree, shape or enact their environment" (Pfeffer \& Salancik, 1978, p. 135).

Pfeffer and Salancik (1978) argued that dependence is a measurement of how important resource suppliers are to an organization. This measurement might influence the position of the resource supplier in the organization's strategic plan. In Pfeffer and Salancik's view, any component of the external technical environment should be, to some extent, important for the organization's survival. It is critical to know how important each one is. 


\section{Institutional Theory as a Model for Understanding Environmental Influences}

Selznick (1966, p. 251) stated that formal organizations are a product "of forces tangential to their rationality, ordered structures and stated goals". As Scott (1998, p. 117) argued "the socially constructed belief exercises enormous control over organizations on both how they are structured and how they carry out their work". Focusing on environmental influences on organizations, the Institutional Theory can be regarded as complementary to the Resource Dependence Theory, because it covers the other aspects of the organization's relationships with the environment, excepting resources. Indeed, an organization's behavior is the result of joined forces within its environment, of which the task environment is a component (Tucker, Baum, \& Singh, 1992).

Scott (1998) argues that it is the environmental pressures that make the organization conform to the social and cultural worlds, and this is central to the institutional theory. Within institutional influences, there are some invisible forces pressing the organization to adhere to taken-for-granted rules and norms (Oliver, 1991).

Often, organizations feel threatened by the prospect of being singled out, and they decide to be isomorphic with other successful organizations. DiMaggio and Powell (1991, p. 66 as cited in Hawley, 1968) defined "isomorphism as a constraining process that forces one unit in a population to resemble other units that face the same set of environmental conditions." For this reason, and being constrained by similar environmental forces, organizations begin to look alike (Orrù et al., 1991).

DiMaggio and Powell (1991, p. 67-69) identified three types of institutional isomorphism:

- Coercive isomorphism that stems from the necessity of the organization to follow legal rules in order to achieve legitimacy;

- Mimetic isomorphism resulting from the phenomenon of the organizations copying each other because they have no means to cope with environmental uncertainty;

. Normative isomorphism resulting from an organization being obligated to adopt patterned behaviors institutionalized by the authorities.

Institutional forces influence organizations to adopt new structures and behaviors institutionalized by their peers or superior forces. Sometimes, this situation is comfortable because by adopting institutionalized elements the organization might avoid its behavior being questioned (Meyer \& Rowan, 1991). 


\section{Stakeholder Theory as a Theoretical Alternative for Converging Resource Dependence and Institutional Theories}

Oliver (1991) suggested the Resource Dependence and Institutional theories to identify strategic responses to institutional processes. Greening and Gray (1994) also applied this approach to investigate organizational responses to social and political issues. Both authors have initially devised their theoretical framework starting from Resource Dependence and Institutionalism perspectives and justified the choice arguing that the Stakeholder Theory is an alternative theoretical bridge linking the two perspectives. The main justification is based on the fact that an organization, in order to survive, needs to manage the issues raised in its environment (technical and institutional). According to them, both theories offer feasible strategic tools to explain and manage such adversities.

\section{Stakeholder Concept, Typology and Importance for the Organization Theory}

Freeman (1984), in a widely quoted book within stakeholder theory, argued that stakeholders can be people, groups and organizations that have some interest in an organization's success. They have power to influence the organization's behavior and performance and they are affected by the organization's operation and outcomes (David, 1995; Shawn, Andrew, Suresh, \& Thomas, 1999).

Freeman (1984) suggested the stakeholder analysis process for scanning the organization's external environment in order to identify opportunities and threats as well as to improve the exercise of the organization's value judgment. To this end, he suggests that a map of the main external agents who are likely to influence or be influenced by the organization should be drawn up.

Bryson (1995) argued that, besides looking for external opportunities and threats, an organization's objectives are also defined by looking at its internal strengths and weaknesses. Furthermore, some sort of balance needs to be sought between the organization's objectives and the diversity of its stakeholders' interests due to resource limitation (Greenley \& Foxall, 1997).

Strengthening the arguments above, Pfeffer and Salancik (1978, p. 43) argued: "Organizations could not survive if they were not responsive to the demands from their environment. On the other hand, if an organization responds completely to environmental demands it would not survive as well". 


\section{Stakeholder Identification and Salience}

Stakeholders have been classified in two ways.

On the one hand, Savage, Nix, Whitehead and Blair, (1991) argued that stakeholders could be classed as primary or secondary. Primary stakeholders are those who have formal and economical relationships with the organization. Secondary stakeholders are those agents not directly related to the organization despite their ability to influence and be influenced by its operation and outcomes.

On the other hand, Atkinson, Waterhouse and Wells, (1997) argued that stakeholders can be seen as environmental or process related. Environmental stakeholders are those included within the external environment in which the organization operates. For Atkinson et al. (1997, p. 27) "this group defines the company's external environment that, in turn, defines the critical elements of its competitive strategy". Process related stakeholders are employees and suppliers, and this group is engaged "to plan, design, implement, and operate the process that makes and delivers the company's products to its customers" (Atkinson et al., 1997, p. 27).

Contributing with a general stakeholder identification theory, Mitchell, Agle and Wood (1997, p. 854) proposed a model based on three dimensions: "(1) the stakeholder's power to influence the firm, (2) the legitimacy of the stakeholder's relationship with the firm, and (3) the urgency of the stakeholder's claim on the firm". The bases of the three dimensions are dealt with as follows.

\section{Power}

According to Mintzberg (1983), power is the capacity to make someone do what he or she would otherwise not do. To achieve this, he suggested five bases of power:

. Control of resources;

. Control of a technical skill;

. Control of a body of knowledge;

. Power from legal prerogatives; and

. Access to those who may rely on the previous sources of power. 
Mitchell et al. (1997, p. 865) suggested that power is likely to result from three contextual dimensions: normative power, coercive power, and utilitarian power. Normative power results from laws and requirements over which the organization has no control. Coercive power issues from physical means. Utilitarian power results from dependence (Pfeffer \& Salancik, 1978), because an organization, sometimes and in some ways, has to behave against its own will in order to achieve resources.

Hardy (1966) suggested that power stems from resources, processes and meaning. The first dimension of power is derived from the ownership of resources. People who own some type of resources are more likely to coerce others into behaving according to their will. For example, "information, expertise, political access, credibility, stature and prestige, access to higher echelon members, the control of money, rewards and sanctions" (Hardy, 1996, p. S7). Pfeffer and Salancik (1978) employed this concept of power to explain dependency. Power also stems from the decision-making process, and people who have domination over such processes are entitled to coerce others by applying or not applying "procedures and political routines" (Hardy, 1996, p. S7). The third dimension of power relates to the power to prevent "conflict from emerging in the first place" (Hardy, 1996, p. S8). That is, some people have control over the status quo, and by doing so they can suppress others from their cognition. These two bases of power can also be related to environmental influences upon organizations in the extent that political and professional issues arise from their pressuring the organization to comply with their requirements.

\section{Urgency}

Mitchell et al. (1997) pointed out the urgency dimension to understand the interactions within stakeholder-managers relationships by encompassing its dynamic scope. They defined it as "the degree to which stakeholder claims call for immediate attention" (Mitchell et al., 1997, p. 867) and that it is related to the conditions through which this type of relationship comes about. In this way, they proposed the dimension urgency as having two attributes: "(1) Time sensitivity - the degree to which managing delay in attending to the claim or relationship is unacceptable to the stakeholder, and (2) criticality - the importance of the claim or the relationship to the stakeholder" (Mitchell et al., 1997, p. 867). 


\section{Legitimacy}

Mitchell et al. (1997) defined legitimacy as "a generalized perception or assumption that the actions of an entity are desirable, proper, or appropriate within some socially constructed systems of norms, values, beliefs, and definitions" and they regarded this dimension as critical to a stakeholder's identification. Sometimes an actor has a stake in the organization, but this demand is neither legal nor moral. They also suggested that only actors who have legitimate stakes are to be regarded as proper stakeholders.

In short, stakeholders have an interest in or power over an organization's operations and objectives. Freeman (1984) offered a grid for mapping the organization's stakeholders based on these categories. In this model, one dimension relates to the diversity of interests that attracts an external agent to the organization and makes it a stakeholder. The other dimension relates to the power that some agents have to influence an organization's behavior and performance.

\section{The Stakeholder's Importance}

A stakeholder's importance for a given organization can be realized by the following statements: "Minimizing the stakeholders' dissatisfaction should be a concurrent objective of 'excellent' companies" (Chakravarthy, 1986, p. 448, inverted commas as in original). Pfeffer and Salancik (1978, p. 2) corroborated this assumption by stating that: "Our position is that organizations survive to the extent that they are effective. Their effectiveness derives from the management of demands, particularly the demands of interest groups upon which the organizations depend for resources and support".

An ultimate reading of active stakeholder management is to be found in Greenley and Foxall (1998, p. 259) "Orientation to the diverse interests of stakeholder groups is central to strategic planning, and failure to address the interests of multiple stakeholders groups may be detrimental to company performance". These statements stress stakeholder satisfaction as the ultimate objective of an environment-steered organization. Some authors contend that stakeholder theory is a new theory of the firm (Key, 1999; Rowley, 1997) replacing the old economic paradigm for an updated ethic view on the relationships between firms and their constituencies. 


\section{The Stakeholder's Analysis}

In order to identify the relevant stakeholders, a process of analysis is proposed. Bryson (1995) and Joyce (1999) suggested the following checklist:

. Identification of the stakeholders;

. Identification of how stakeholders are able to influence the organization;

. Identification of what the organization needs from each stakeholder;

- Identification of the criteria used by the stakeholder for evaluating the organization's performance;

\section{Ranking the Stakeholder's Importance}

As a stakeholder is likely to represent an opportunity as well as a threat, the organization needs to know how influential each stakeholder is and to what extent $\mathrm{s} /$ he represents a threat or an opportunity to the organization's strategic management. Savage et al. (1991) classified a stakeholder's relative importance into capacity for threat to the organization, and potential to co-operate with the organization. Table 1 presents the stakeholder classification and suggests four different strategies for dealing with them.

\section{Table 1: Mapping the Stakeholder's Relative Importance for the Organization}

\begin{tabular}{|c|c|c|c|}
\hline & & \multicolumn{2}{|c|}{ Capacity for threat } \\
\hline & & Low & High \\
\hline \multirow{2}{*}{$\begin{array}{l}\text { Potential for } \\
\text { co-operation }\end{array}$} & High & $\begin{array}{c}\text { Stakeholder type } 1 \\
\text { Supportive } \\
\text { Strategy: involve }\end{array}$ & $\begin{array}{c}\text { Stakeholder type } 4 \\
\text { Mixed Blessing } \\
\text { Strategy: collaborate }\end{array}$ \\
\hline & Low & $\begin{array}{c}\text { Stakeholder type } 2 \\
\text { Marginal } \\
\text { Strategy: monitor }\end{array}$ & $\begin{array}{c}\text { Stakeholder type } 3 \\
\text { No supportive } \\
\text { Strategy: defend }\end{array}$ \\
\hline
\end{tabular}

Source: adapted from Savage et al., 1991. 


\section{Summing up the Theoretical Background}

The starting point of the theoretical framework is the Open Systems perspective, which proposes the view for understanding the organizations' relationships with their external environment (Hannan \& Freeman, 1977; Katz \& Kahn, 1978; Pfeffer $\&$ Salancik, 1978; Selznick, 1966). In this process, organizations need to acquire and maintain resources in order to keep their operative process running (Oliver, 1997). They also have to seek support and legitimacy for their activities and goals (Oliver, 1997; Pfeffer \& Salancik, 1978). The whole process of gathering resources and achieving legitimacy happens because an organization does not exist in a vacuum (Child, 1976), nor is it able to survive by itself (Pfeffer, 1982). Organizations have to negotiate all the time with external agents for resources of all kind (Scott, 1998). This process leads organizations to seek links and relationships with the external environment in order to survive (Hannan \& Freeman, 1978).

The technical and institutional environments influence an organization's behavior (Orru et al., 1991). Resource dependence theory explains how an organization becomes attached to its environment to the extent that it needs resources (Pfeffer \& Salancik, 1978). Institutional theory explains how an organization becomes isomorphic with its environment to the extent that it accepts, as taken-for-granted, the institutions generated in its environment. Both theories try to explain an organization's behavior as influenced by the external environment and the extent that these influences shape an organization's choices (Greening \& Gray, 1994).

Oliver (1991, p. 146) argued that "according to both institutional and resource dependence perspectives, organizational choice is limited by a variety of external pressures". Greening and Gray (1994, p. 469) argue that "both institutional and resource dependence theory offer explanations for why firms adopt certain structural modification”. Both Oliver (1991) and Greening and Gray (1994) suggested the Stakeholder Theory to understand the relationships between an organization and its environment. In the same vein, Abzug and Webb (1999, p. 420) argued: "We can think about stakeholder theory as an encompassing (macro) theory that helps to bring institutional, competitive, and dependence forces - and competitive forces - into a unified theory". Through resource dependence theory, stakeholders can be seen as environmental agents who own the organization's required resources (Frooman, 1999). Through institutionalism, theory stakeholders can be seen as the environmental agents who produce the rules and the takenfor-granted behaviors in which the organization bases its own behavior in order to achieve legitimacy and acceptance (Greening \& Gray, 1994). 


\section{Figure 1: The Theoretical Framework Diagram}

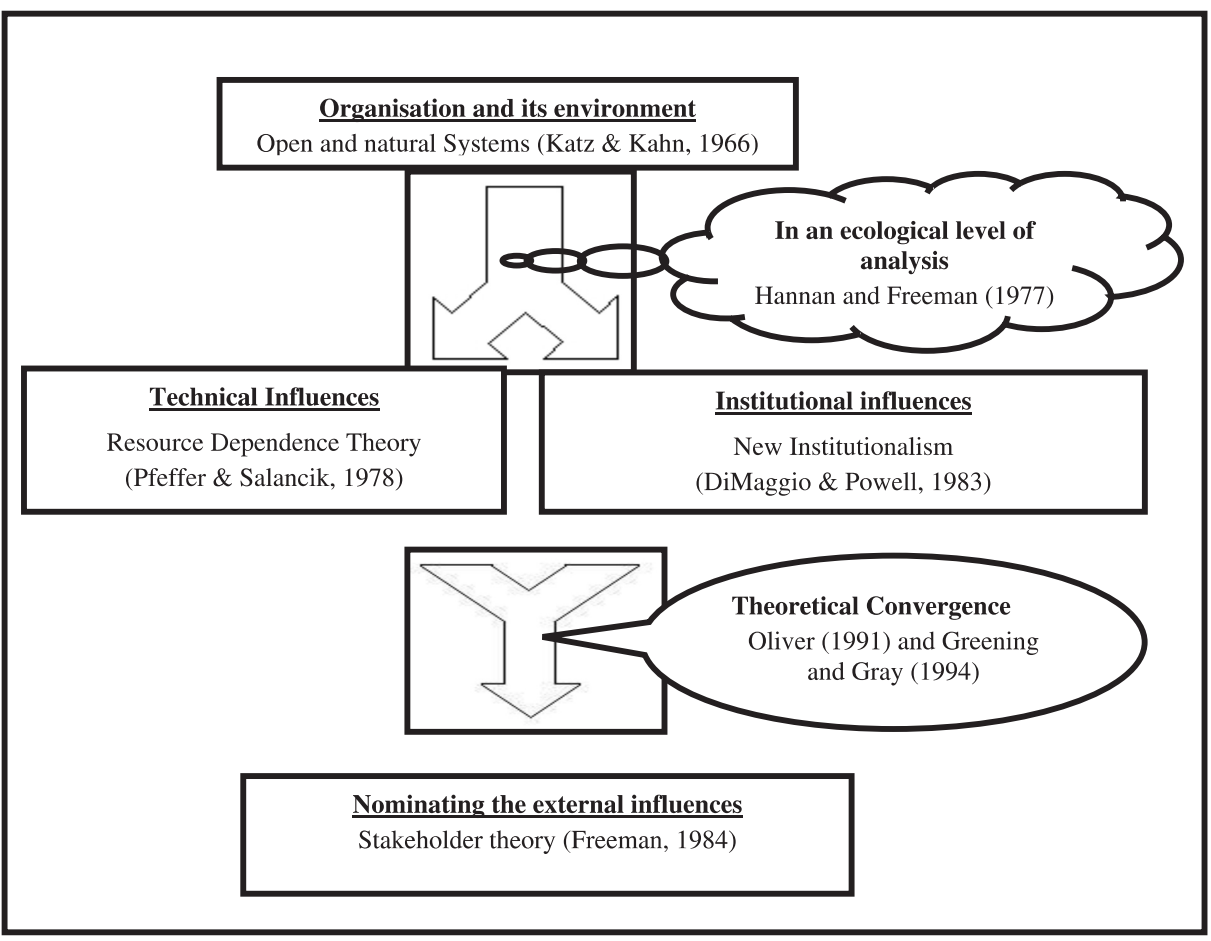

According to Donaldson and Preston (1995), the investigations which employed the Stakeholder Theory have been undertaken on three different bases: descriptive accuracy, instrumental power and normative validity.

By exploring descriptive accuracy, there are several studies seeking to determine the sort of stakeholder able to participate in the decision-making process of profitseeking organizations, for example: Freeman (1984), Clarkson (1995), and Atkinson et al. (1997). Abzug and Webb (1999) used the Stakeholder Theory to describe a set of stakeholders for non-profit organizations. Bryson (1995) suggested a stakeholder set for public organizations and Rogers (1999) suggested a list of stakeholders for the Best Value process.

By investigating instrumental power, there are studies dedicated to identifying the relationship between stakeholder management and performance, such as Ullmann (1985) who examined several empirical studies on U.S. corporations and concluded that stakeholder power is positively correlated with the organization's social performance. Another example is Greenley and Foxall (1997, p. 20-21) who studied UK companies and concluded that: "companies should achieve a balance in addressing stakeholder interests, rather than 
selectively prioritizing their attention and resources allocation to certain groups".

Exploring the normative basis, Freeman (1984) proposed a two dimensional grid based on power and interest to identify the relevant stakeholder for the organization. Savage et al. (1991) proposed a methodology for assessing stakeholder management based on a stakeholder's potential to co-operate and/ with or to threaten the organization. In addition to these studies, Berman, Wicks, Kotha and Jones (1999) tested the descriptive accuracy of two stakeholder management models and the relationships between these models and a firm's performance. Frooman (1999) proposes managerial strategies to deal with technical stakeholders. Ullmann (1995) discovered that stakeholder power is positively correlated with the organization's social performance. Greening and Gray (1994) developed and tested a model for explaining how firms respond to technical and institutional environmental influences. Harrison and ST John (1996) suggested that organizations should seek the stakeholder's partnership rather than stakeholder management. Finally, Mitchell et al. (1997) proposed a framework for stakeholder identification and salience.

In public or non-profit organizations, there are some examples of normative stakeholder theories, such as Bryson (1995), who proposed a stakeholder set for government. Joyce (1999) proposed that stakeholder analysis should be applied in the planning process of public organizations. Winstanley, Sorabji and Dawson (1995) suggested criteria for assessing stakeholder power for influencing public sector restructuring. Fottler, Blair and Savage (1989) suggested strategies for negotiating with stakeholders of hospitals. Savage, Nix, Whitehead and Blair (1997) suggested models of integrated delivery services and networks to cope with environmental demands in the health care sector.

Other studies have been dedicated to identifying the stakeholders themselves. Within these descriptive studies, Brennan and Douglas (1998, p. 243) suggested that, in the strategic management of local governments, "the key stakeholders are consumers, employees and elected members". Fottler et al. (1989) researched key stakeholders of hospitals. While Miller and Wilson (1998) researched an NHS trust seeking to identify the significance of stakeholding in this type of organization. Finally, Rizzo (1987) explored the stakeholders for educational organizations.

As indicated above, there is still a considerable field to be researched in stakeholder theory with special reference to public services. For this reason, an investigation in this field needs to take place in order to fulfill three objectives: 
. Descriptive: empirical investigations seeking to identify a reliable set of stakeholders in the decision-making process of public organizations;

- Instrumental: empirical investigations seeking to identify the causal relationships between stakeholder influences and organizational performance; and

. Normative: empirical investigations seeking to propose models for explaining the interaction between stakeholder influences and decision-making.

\section{Conclusions}

This paper has presented a literature review on organizations theory with specific focus on the organization's relationships with its environment. In so doing, it presented the relevant organization theory that explains how an organization's behavior and performance is likely to be influenced by environmental influences. The exercise showed that the Stakeholder Theory is a feasible approach to understanding the sort of influences an organization receives as populating environments.

The applications of this paper rely upon a theoretical framework which is based on an extensive literature review encompassing environment based theories. In this way, this paper would help researchers looking at the whole set of organizations' relationships with their environment and not only their relationships with external agents. Employing the theoretical basis presented in this analysis, one will be able to identify both feasible theoretical sources for his/her studies and useful approaches for carrying on his/her investigations.

The literature review started from the Open Systems Theory for explaining how an organization behaves in active environmental conditions. Then, Resource Dependence and Institutional theories were suggested as acceptable explanations for the fact that the organization's survival is directly related to the degree of ability to adapt to environmental changes. Associating Resource Dependence with Institutionalism theories and based on past experiences (Abzug \& Webb, 1999; Greening \& Gray, 1994; Oliver, 1991), the paper proposed the Stakeholder Theory as a bridge to merge the two theories in order to explain the organization's behavior as affected by technical and institutional influences from its environment.

The literature review presented several models of stakeholder identification and salience. The stakeholder concept is borrowed from Freeman's landmark contribution (1984, p. 46) to strategic management, which is defined as "any group or individual who can affect or is affected by the achievement of the 
organization's objectives". The concept assumes a bilateral nature of the relationships between an organization and its stakeholders based on the organization's ability to exert influence over them and the likelihood of suffering influences from them.

The stakeholder theory framework prescribes models for identifying the relevant stakeholders and the extent to which they can be seen as channels through which influence travels to reach the organization. It also prescribes more complex models that connect stakeholder identification with measurements of power to influence the organization. These measurements of power are based on control over resources, processes and the institutional power to set norms and values with which the organization must comply.

In this paper, a theoretical framework for investigating the organization's relationships with environmental influences was proposed. As the review demonstrated, the framework has been tested in the business sector with attention to the public and non-profit sectors. In this way, the paper suggested that this framework is very likely to be successfully employed in different types of organizations.

\section{Artigo recebido em 05.05.2004. Aprovado em 30.11.2004.}

\section{References}

Abzug, R., \&

Webb, N. J. (1999).

Relationships between nonprofit and for-profit organizations: a stakeholder perspective. Nonprofit and Voluntary Sector Quarterly, 28(9), 416-431.

Ansof, H. I. (1988).

The new corporate strategy. New York: Willey.

Atkinson, A. A.,

Waterhouse, J. H., \&

Wells, R. B. (1997, Spring).

A stakeholder approach to strategic performance measurement. Sloan Management Review, 38, pp. 25-37.

Berman, S. L.,

Wicks, A. C.,

Kotha, S., \&

Jones, T. M. (1999).

Does stakeholder orientation matter?

The relationship between stakeholder management models and firm financial performance. Academy of Management Journal, 42(5), 488-506.

Boulding, K. E. (1956).

General systems theory: the skeleton of science. Management Science, 2(3), 197-208. 
Brennan, C., \&

Douglas, A. (1998).

Developing a process model for standard setting in local government services. Managing Service Quality, 8(4), 241-247.

Bryson, J. (1995).

Strategic planning for public and non-profit organization. San Francisco: Jossey-Bass Publishers.

Chakravarthy, B. S. (1986).

Measuring strategic performance: summary. Strategic Management Journal, 7(5), 437-458.

Child, J. (1973).

Managerial and organizational factors associated with company performance. Birmingham: Aston University.

Child, J. (1976).

Organization design and performance: contingency theory and beyond. Birmingham: Aston University.

Clarkson, M. B. E. (1995).

A stakeholder framework for analyzing and evaluating corporate social performance. Academy of Management Review, 20(1), 92-117.

David, F. R. (1995).

Concepts of strategic management. New Jersey: Prentice Hall.

DiMaggio, P. J., \&

Powell, W. W. (1991).

The iron cage revisited: institutional isomorphism and collective rationality in organizational fields. In W. W.
Powell, \& P. J. DiMaggio (Eds.). The

new institutionalism in organizational analysis. Chicago: The University of Chicago Press.

Donaldson, T., \&

Preston, L. E. (1995).

The Stakeholder theory of the corporation: concepts, evidences. Academy of Management Review, 20(1), 65-91.

Fottler, M.,

Blair, J. D., \&

Savage, G. T. (1989).

Assessing key stakeholders: Who matters to hospitals and why? Hospital \& Health Services Administration, 34(4), 525-546.

Freeman, R. E. (1984).

Strategic management: a stakeholder approach. Massachusetts: Pitman.

Frooman, J. (1999).

Stakeholder influences strategies. Academy of Management Review, 24(2), 191-205.

Greening, D. W., \&

Gray, B. (1994).

Testing a model of organizational response to social and political issues. Academy of Management Journal, 37(3), 467-498.

Greenley, G. E., \&

Foxall, G. R. (1998).

External moderation of associations among stakeholder orientations and company performance. International Journal of Research in Marketing, 15(1), 51-69. 
Greenley, G. E., \&

Foxall, G. R. (1997).

Multiple stakeholder orientation in UK companies and the implications for company performance. Journal of Management Studies, 34(2), 259-284.

Greenwood, R., \&

Hinings, C. R. (1996).

Understanding radical organizational change: bringing together the old and the new institutionalism. Academy of Management Review, 21(4), 1022-1054.

Hannan, M. T., \&

Freeman, J. (1977).

The population ecology of organizations. American Journal of Sociology, 82(5), 929-964.

Hardy, C. (1996)

Understanding power: bringing about strategic change. British Journal of Management, 7(s1), S3-S16.

Harrison, J. S., \&

John, C. H. St. (1996).

Managing and partnering with external stakeholders. Academy of Management Executive, 10(2), 46-60.

Hawley, A. (1968).

Human ecology. In D. L. Sills (Ed.). International encyclopedia of the social science. New York: Macmillan.

Joyce, P. (1999).

Strategic management for the public services. Philadelphia: Open University Press.

Katz, D., \&

Kahn, R. L. (1978).

The social psychology of organizations. New York: John Wiley \& Sons, Inc.
Key, S. (1999).

Toward a new theory of the firm: a critique of stakeholder theory. Management Decision, 37(10), 317-328.

Lawrence, P. R., \&

Lorsch, J. W. (1967).

Organization and Environment: managing differentiation and integration. Boston: Harvard University Press.

Meyer, J. W., \&

Rowan, B. (1991).

Institutionalized organizations: formal structure, myth, and ceremony. In W. S. Powell, \& P. J. DiMaggio (Eds.). The new institutionalism in organizational analysis. Chicago: The University of Chicago Press.

Miller, S., \&

Wilson, J. (1998, July/September).

Perceptions of stakeholding: the case of a NHS trust. Public Money \& Management, 18(3), 51-58.

Mintzberg, H. (1983).

Power in and around organizations. New Jersey: Prentice Hall, Inc.

Mitchell, R. K.,

Agle, B. R., \&

Wood, D. J. (1997).

Toward a theory of stakeholder identification and salience: defining the principle of the who and what really counts. Academy of Management Review, 22(4), 853-886.

Mwankwo, S., \&

Richardson, B. (1996).

Organizational leaders as political strategists: a stakeholder management perspective. Management Decision, 34(10), 43-49. 
Oliver, C. (1990).

Determinants of interorganizational relationships: integration and future directions. Academy of Management Review, 15(2), 241-265.

Oliver, C. (1991).

Strategic responses to institutional processes. Academy of Management Review, 16(1), 145-179.

Oliver, C. (1997).

Sustainable competitive advantage: combining institutional and resourcebased views. Strategic Management Journal, 18(9), 697-713.

Orrù, M.,

Biggart, N. W., \&

Hamilton, G. G. (1991).

Organizational isomorphism in East Asia. In W. S. Powell, \& P.J. DiMaggio (Eds.). The new institutionalism in organizational analysis. Chicago: The University of Chicago Press.

Pfeffer, J. (1982).

Organizations and organization theory. Boston: Pitman Publishing Inc.

Pfeffer, J., \&

Salancik, G. R. (1978).

The external control of organizations: a resource dependence perspective. New York: Harper and How.

Rizzo,A. (1987).

Stakeholders in public sector education: an alternative approach. American Review of Public Administration, 17(4), 87-92.

Rogers, S. (1999).

Performance management in local government. London: Financial Times Professional Limited.
Rowley, T. (1997).

Moving beyond dyadic ties: a network theory of stakeholder influences. Academy of Management Review, 22(4), 887-910.

Roy, C., \&

Séguin, F. (2000).

The institutionalization of efficiencyoriented approaches for public service improvement. Public Productivity \& Management Review, 23(4), 449-468.

Savage, G. T.,

Nix, T. W.,

Whitehead, C. J., \&

Blair, J. D. (1991).

Strategies for assessing and managing organizational stakeholders. Academy of Management Executive, 5(2), 6176.

Savage, G. T.,

Nix, T. W.,

Whitehead, C. J., \&

Blair, J. D. (1997).

Governance of integrated delivery systems/networks: a stakeholder approach. Health Care Manage Review, 22(1), 7-20.

Scott, W. R. (1998).

Organizations rational, natural, and open systems. New Jersey: PrenticeHall Inc.

Scott, W. R., \&

Meyer, J. W. (1991).

The organization of societal sectors: propositions and early evidence. In W. S. Powell, \& P. J. DiMaggio (Eds.). The new institutionalism in organizational analysis. Chicago: The University of Chicago Press. 
Selznick, P. (1966).

Tva and the grass roots: a study in the sociology of formal organization. New York: Harper Torchbooks.

Shawn, L. B., Andrew, C. W.,

Suresh, K., \&

Thomas, M. J. (1999).

Does stakeholder orientation matter? The relationship between stakeholder management models and firm financial performance. Academy of Management Journal, 42(5), 488-506.

Tucker, D. J.,

Baum, J. A. C., \&

Singh, J. V. (1992)

The institutional ecology of human services organizations. In Y. Hasenfeld (Ed.). Human services as complex organizations. California: Sage Publications.
Ullmann, A. A. (1985).

Data in search of a theory: a critical examination of the relationships among social performance, social disclosure, and economic performance of U.S. firms. Academy of Management Review, 10(3), 540557.

Williamson, O.E. (1975).

Markets and hierarchies: analysis and antitrust implications. New York: Free Press.

Winstanley, D., Sorabji, D., \&

Dawson, S. (1995, April/June).

When the pieces don't fit: a stakeholder power matrix to analyse public sector restructuring. Public Money \& Management, pp.19-26.

Woodward, J. (1965).

Industrial organizations: theory and practice. New York: Oxford University Press. 
